\title{
KIR2DS4 wt Allele
}

National Cancer Institute

\section{Source}

National Cancer Institute. KIR2DS4 wt Allele. NCI Thesaurus. Code C118917.

Human KIR2DS4 wild-type allele is located in the vicinity of 19q13.4 and is approximately $16 \mathrm{~kb}$ in leng th. This allele, which encodes killer cell immunog lobulin-like receptor 2DS4 protein, is involved in natural killer cell-mediated immunity. 